\title{
ILLÉS Mária
}

\section{A BERUHÁZÁSI PROJEKTEK AGGREGÁLT TŐKEIGÉNYE}

A tanulmány abból indul ki, hogy a beruházási projektek értékelése során egyidejúleg szükséges figyelembe venni a projektben lekötött tốkét és a lekötési idốt mint jövedelemtermelési lehetốséget. Definiálja a projekt aggregált tốkeigényének fogalmát és megszerkeszti a vonatkozó mérőszámot. Az aggregált tókeigény új vállalatgazdasági kategória, mely a beruházási projektek értékelésének egy új megközelítését teszi lehetốvé. A projekt aggregált tốkeigénye azt a tốkeösszeget jelenti, mely a projekt múködtetéséhez annak teljes élettartama alatt szükséges. A három meghatározó tényezô: a kezdốtóke, a megtérülési idő (illetốleg az élettartam) és a megtérülés gyorsasága. A számszerúsítéshez minden évre vonatkozóan meg kell határozni az adott évben lekötött tókét, ami az adott évig még meg nem térült tókerészt jelenti, majd ezek összegzése révén adódik az aggregált tốkeigény. A mértékegység egységnyi tốke egyévi lekötése. A tanulmány az összefüggések modellszerú levezetése mellett gazdag példaanyagot is tartalmaz. Az elemzés bôvíti a nettó jelenérték tartalmára vonatkozó ismereteket, rávilágít az aggregált tókeigény ismeretének fontosságára mind a nettó jelenérték, mind a belsó kamatláb esetében.

Kulcsszavak: nettó jelenérték, belsố kamatláb, aggregált tớkeigény, nyereségkövetelmény, rangsorképzés

Egy projekt vállalaton belüli súlyának, és az általa igénybe vett vállalati erôforrások értékének egyik fontos gazdasági jellemzóje az összesített tókeigény. Az irodalom ezzel a kérdéssel nem foglalkozik. Az összeg becslése - a fogalom újszerúségéból és a számítás modellszerú leírása alapján - kissé bonyolultnak látszik, azonban a gyakorlati számítás jelentôsen egyszerúbb. Az általa nyújtott információ több gazdálkodási összefüggést új megvilágításba helyezhet.

Bizonyos számításokban, amikor valójában az öszszes tókkeigény figyelembevétele lenne indokolt, a kezdôtôke összege, illetôleg az élettartam szerepel. Ez utóbbi megoldások módszertanának helyessége tisztázatlan.

Jelen tanulmány fő́bb célkitúzései:

1. rámutatni a beruházásgazdaságossági számításoknak a tudományos alapok eltérésében gyökerezô ellentmondásaira, majd vállalat-gazdaságtani szemléletben bemutatni a nettó jelenérték és a tốke tartalmi összefüggéseit,

2. definiálni és értelmezni az aggregált tókeigény fogalmát,
3. modellszerúen bemutatni a projekt aggregált tôkeigényének becslési folyamatát és számszerúsíteni az aggregált tókeigényt,

4. rámutatni az aggregált tốkeigény ismeretének jelentőségére.

A vizsgálódások egyik alapkategóriája a hozadék, mely egy adott év összes bevételének és összes kiadásának a különbségét számszerúsíti.

Az elemzések és megállapítások mindvégig a tipikus hozadéksorú (ortodox, konvencionális) beruházási projektekre vonatkoznak. A tipikus hozadéksor közismert kritériuma: az éves bevételi és kiadási összegek különbségeként összeállított hozadéksor negatív elôjelú összeggel vagy összegekkel kezdődik, és csak egyszer vált elójelet. Ha tehát az idősor valamely évében a bevétel összege meghaladja a kiadásét, utána már nem következhet olyan év, ahol a kiadás lenne a nagyobb.

A vizsgálódás körének a tipikus hozadéksorú beruházásokra való szúkítését az indokolja, hogy a két legnagyobb súllyal alkalmazott módszer, a nettójelenértékszámítás és a belsókamatláb-keresés alkalmazása csak ebben aberuházási körben vezetegyértelmúeredményre. 
Közismert, hogy nem tipikus hozadéksor esetén több belsố kamatláb is adódhat. Ezzel szemben vitatható szakirodalmi egyetértés mutatkozik a nettó jelenérték alkalmazhatóságának kérdésében. Abból kiindulva, hogy a hozadéksor típusától függetlenül a számítás eredményeként csak egy nettó jelenérték jöhet ki, ezt a módszert bármely projektre alkalmazhatónak tekintik (például Arnold - Hope, 1990). Az összefüggések mélyebb elemzése alapján belátható, hogy a nem tipikus hozadéksorú beruházások esetében a nettó jelenérték sem mutatja megbízhatóan a megtérülési követelmények teljesülését (Illés, 2007).

Az egyértelmúség érdekében a tanulmány csak saját tốke igénybevételével számol, továbbá a nyereséget adózatlan nyereségként és projektszinten értelmezi. (A vállalati szinten veszteségcsökkenést eredményezô beruházás önmagában nézve nyereséges, viszont vállalati szinten nem jelentkezik a nyeresége, így nem nyereségadó-köteles.)

A tớke szúkebb értelmezésben pénztókeként, azaz befektethetô, illetve befektetett pénzeszközként szerepel. Egy olyan összeg, ami - éves szakaszolás szerint - már ki van fizetve, de még nem térült meg. (Az összeget technikailag növelheti a kalkulatív kamatláb szerinti nyereségkövetelmény adott évben meg nem térült része is.)

A tanulmány vállalat-gazdaságtani szemléletet, megközelítésmódot és feltételrendszert alkalmaz.

\section{A közismert beruházásgazdaságossági számítások diszciplináris alapjai}

Immár mintegy nyolc évtizede napirenden lévő vitatéma, hogy a nettójelenérték-(NPV, Net Present Value) számítás és a belsốkamatláb-(IRR, Internal Rate of Return)keresés módszere közül melyik a jobb. A pénzügytani irodalom igen határozott nettójelenértékpreferenciát fogalmaz meg. Ennek ellenére a fejlett gazdaságú országok vállalati szakemberei a döntéseik megalapozásához nagy súlyarányban a belsố kamatlábat alkalmazzák. (A vállalatok által alkalmazott módszerek világszerte folyó kutatásáról Szúcsné Markovics (2012) ad szakirodalmi áttekintést.)

Volkman (1997) kutatásai szerint a vita és a fenti összhanghiány arra vezethetố vissza, hogy a pénzügytan a nettójelenérték-számítás előnyösebb voltát Fishernek egy a múlt század első felében megjelent munkájára alapozva hirdeti (Fisher, 1930). Ezzel szemben a vállalatgazdászok elsősorban Böhm-Bawerk német és angol nyelven kiadott világhírú munkájára (Böhm-Bawerk, 1889, 1891), majd Keynes (1936) munkásságára alapozva a belsókamatláb-keresés módszerét helyezik előtérbe.
Ez azonban csak a felszín. A kibékíthetetlennek látszó ellentmondások az eltérô diszciplináris alapokban gyökereznek. A pénzügytan ugyanis a standard mikroökonómiára, illetóleg az ortodox közgazdasági elméletre épül (Volkman, 1997), mely igen magas absztrakciós szinten vizsgálja a gazdasági összefüggéseket. A mikroökonómia - több okra visszavezethetően - nem is ad módszertani tanácsokat a vállalati gazdálkodás számára. Ezzel szemben a pénzügytan meglehetôs határozottsággal nyújt gyakorlati iránymutatásokat. Ez utóbbiaknak a vállalatgazdasági szempontú feldolgozását a (többnyire hallgatólagosan alkalmazott) magas absztrakciós szint mellett tovább nehezíti, hogy nem válik egyértelmúvé: mely feltételek és összefüggések származnak közvetlenül a standard mikroökonómiából, illetőleg melyek azok, amelyek kifejezetten a pénzügytan területén keletkeztek. Ez utóbbiak közé tartozik például annak feltételezése, hogy a finanszírozási források tetszólegesen bővíthetók. A feltétel gyakorlati realitása egyszerú tapasztalati alapon is megkérdőjelezhető. Természetesen magas absztrakciós szint mellett is lehet elismerésre méltó tudományos vizsgálatokat végezni, azonban az eredményeknek a gyakorlati élethez való visszacsatlakoztatása (amennyiben ez megtörténik) elôtt a valóságos körülmények között nem érvényesülő feltételeket fel kell oldani, és ennek következményeit az előzőleg kapott összefüggéseken át kell vezetni. (Woods és Randall a pénzügytani alapokon nyugvó, 1989-es közös tanulmányában megkérdőjelezi a pénzügytan több elemzési feltételének gyakorlati létjogosultságát.)

A vállalati gazdaságtan absztrakciós szintje viszonylag alacsony, gazdálkodás-módszertani eredményeinek jelentôs része - az adott vállalat sajátosságaihoz igazítva - közvetlenül hasznosítható a vállalati gazdálkodásban. Szóhasználata összhangban van a vállalati gazdálkodás szóhasználatával. (A pénzügytani és a vállalat-gazdaságtani diszciplínának a vizsgált kérdéskörben meghúzódó fő́bb eltéréseit Illés (2012b) tárja fel.)

Noha jelen tanulmány a vállalati gazdaságtan eszköz- és módszertani bázisán, vállalat-gazdaságtani szemléletben dolgozza fel az aggregált tốkeigény kérdéskörét, arra való tekintettel, hogy a pénzügytan a vállalat beruházási döntéseire vonatkozólag is ad módszertani tanácsokat, ezek domináns elemeire tudományágtól függetlenül ki kell térnie.

\section{A tókeszükséglet kezelése a standard módszertanban}

A dinamikus beruházásgazdaságossági vizsgálatok közismert módszertanának egyik sajátossága, hogy nem vizsgálja a projekt összesített tókeigényét. A gaz- 
daságosság alapvetô kérdése, nevezetesen, hogy teljesül-e a tókének, valamint a hozamkövetelményének a megtérülése, természetesen megválaszolható az összesített tókeszükséglet ismerete nélkül is.

A módszertan háttérbázisa a vizsgált projekt mindenkori tôkeigényét igen korrekt módon veszi figyelembe mind jövedelmezôségi elvárás felszámítása, mind a belsố kamatláb meghatározása során, és megtérülési követelményként helyesen kezeli magát a tôkét is. Mivel a számítás folyamata ezeket az összefüggéseket összevontan kezeli, az igénybe vett tôkére vonatkozó információ a háttérben marad.

Az összesített tôkeigény ismeretének szükségessége a két említett módszer esetében eltérô súlyú. A belsô kamatláb tipikus hozadéksorú beruházások esetén a projektbe befektetett tôke átlagos jövedelmezôségi rátáját mutatja (Illés, 1990). Maga a ráta értelmezhető az össztốkeszükséglet számszerúsítése nélkül is. A tisztánlátás érdekében azonban hasznos lenne azt is tudni, hogy mekkora az a tókeösszeg, mely az adott jövedelmezőség mellett van befektetve a projektbe. Ebben az összefüggésben az a szerencsés, ha minél nagyobb tôkeösszeg eredményez, minél nagyobb tókejövedelmezôséget (belső kamatlábat).

A pozitív összegú nettó jelenérték (tipikus hozadéksorú projektek esetén) azt mutatja meg, hogy a tôkelekötés elvárt hozamkövetelménye felett keletkező hozamtöbbleteknek mekkora a jelenértéke. (Tartalmi meghatározás: Illés, 1990, bizonyítás: Illés, 2012a.) Ha csak az a kérdés, hogy teljesül-e a megtérülési követelmény, az a nettó jelenérték alapján is egyértelmúen megválaszolható. Itt azonban különösen fontos lenne az összesített tókeigény ismerete, mivel nem lehet közömbös, hogy a diszkontált hozamtöbblet adott összegének elérése tókeoldalról mekkora vállalati erőfeszítést igényel. Itt az a kedvezőbb változat, ha minél kisebb össztőkelekötés révén lehet minél nagyobb összegú többlethozamot elérni.

Szakirodalmi egyetértés mutatkozik abban a kérdésben, hogy a nettó jelenérték és a belsô kamatláb módszere ugyanazokat a beruházásokat mutatja gazdaságosnak, illetôleg gazdaságtalannak. Pénzügytani szóhasználat szerint mindkét módszer ugyanazokat a projekteket válogatja ki megvalósítandó, illetôleg elvetendő változatként. (Lényegében ezt vallja például Bierman - Smidt, 1986; Firer - Gilbert, 2004; Brigham - Ehrhardt, 2008; Khan - Jain, 2008; Kinney - Raiborn, 2012 stb.) Természetesen a megegyezô szelekcióra vonatkozó összefüggés is csak a tipikus hozadéksorú beruházások körére érvényes. (Több belső kamatláb esetén még formailag sem lehet szelekciót alkalmazni.)

A szelekcióra vonatkozó egyetértés ellenére is megoszlanak a vélemények a módszerválasztás célszerúsé- gérôl. Mint az előzőekben szerepelt, a vállalatgazdászok jelentős súllyal alkalmazzák a belsôkamatláb-keresés módszerét, ezzel szemben a pénzügytanban igen egyértelmú nettójelenérték-preferencia érvényesül.

A pénzügytan nettójelenérték-preferenciája mögött - bizonyos határelmosódásokkal - többféle irányzat tárható fel:

a) a nettó jelenértéket minden szempontból a legjobb módszernek valló irányzat,

b) szelekciós eszközként a nettó jelenértéket, rangsorképzô mutatóként a beruházás egységére jutó nettó jelenértéket (illetôleg a jövedelmezőségi indexet) preferáló irányzat,

c) a nettó jelenérték szerinti szelekciót, továbbá a nettó jelenérték éves gazdasági átlaga szerinti rangsorképzést előnyben részesítő irányzat.

A nettó jelenértéket minden tekintetben legjobbnak tekintő irányzat képviselői a nettó jelenértéket nem csupán szelekciós célra ajánlják kiemelten, hanem az előnyösségi sorrend meghatározására is.

A döntéshozó számára a nettó jelenérték szegényesebb információ, mint a belsô kamatláb. A pozitív előjelư nettó jelenérték a következôt üzeni a döntéshozónak: megtérül az elvárt kamat szerinti hozam, továbbá keletkezik még - jelenértéken számítva - „y” összegú hozamtöbblet. Ha csak az a kérdés, hogy teljesül-e a megtérülési követelmény, ez a válasz megfelelő. Nem könnyú azonban azonnal átlátni, hogy a nettó jelenérték maga valójában mekkora előnyt jelent. Egy egészen hétköznapi példán érzékeltetve: tételezzük fel, hogy valaki 300 ezer eurót szeretne elhelyezni egyéves lekötésú banki kamatozásra. Az egyik bank ajánlata: 4,5 százalék kamat. Ez elsô hallásra is egyértelmú információ. A másik bank azt mondja, ad 3 százalék kamatot, továbbá azonnal visszafizet a betétes számára bónuszként 4500 eurót. Ugyancsak el kellene gondolkozni azon, hogy ez a bónusz összességében mekkora előnyt jelent, illetôleg a bónusszal növelt ajánlat hogyan viszonyul az előzô bank 4,5 százalékos ajánlatához. Többéves lekötés esetén a lekötés idôpontjában kapható bónusz valódi értékének a megítélése még nehezebb (Illés, 2012b). Ezzel szemben (mint a fentiekben szerepelt) a belső kamatláb azt mutatja meg, hogy a projekt tőkejövedelmezősége hány százalékos (a banki példára visszautalva: hány százalék lesz a bónuszt is magában foglaló kamat).

Immár több évtizede ismeretes, hogy az egyes projektek nettó jelenértékei közvetlenül nem hasonlíthatók össze. Torzító hatást válthatnak ki az induló tơkeigénynek, az élettartamnak és a megtérülés sebességének a különbségei (Keane, 1975). Ennek ellenére is fennmaradt a nettó jelenérték egyoldalú ajánlására vonatkozó 
irányzat (például Baker - Powell, 2005; Van Horne Vachowicz, 2008; Crundwell, 2008 stb.). Az irányzat erốs voltát jelzi Laux azon megállapítása, mely szerint a tudományos kutatók a nettó jelenérték módszerét tartják a legjobbnak, és egyes vélemények szerint a jövóben a gyakorlati szakemberek is egyet fognak érteni ezzel (Laux, 2011).

Noha a nettó jelenértékek összehasonlítását a fent jelzett három tényezô torzíthatja, az irodalomban csupán a kezdőtốke és az élettartam különbségéból fakadó torzítás egyfajta egytényezős kiküszöbölésére alakult ki törekvés.

Az egyik irányzat a beruházási összeg egységére jutó nettó jelenértéket, illetôleg a jövedelmezóségi indexet ajánlja a legmegbízhatóbb rangsorképzô mutatóként. A jövedelmezőségi index felírható a következóképpen is: [1 + A beruházás egységére jutó nettó jelenérték]. Tehát a két mutató tartalmi szerkezetében és sorrend-kialakító hatásában nincs érdemi különbség. Rangsorképzési célra a jövedelmezőségi indexet javasolja például Brealey - Myers (1992), Albrecht et al. (2007), Watson - Head (2009). Előfordul, hogy ajánlott jövedelmezôségi indexként megnevezve a beruházás egységére jutó nettó jelenérték szerepel (például Damodaran, 2010).

A nettó jelenérték évi átlagos összegének rangsorképzô mutatóként való ajánlása az utóbbi két évtizedben vált érdemleges súlyúvá. (Ezt javasolja például Helfert, 1991; Baker - Powell, 2005, illetôleg Lee Lee - Lee, 2009.) Az átlag meghatározása úgy történik, hogy a nettó jelenértéket elosztják az annuitási tényezôvel, ami a vállalati gazdaságtanban a törlesztófaktorral való szorzást jelenti. (A törlesztőfaktorral való szorzás évi átlagossá alakít, miközben kamatot számít fel. A ,visszakamatozás” révén eltúnik a mutatószám tartalmának diszkontálási dominanciája.)

A torzító tényezók együttes hatásának figyelembevételét tartalmazó rangsorképző mutató kidolgozására nem mutatkozik törekvés. Amennyiben mindhárom torzító tényező hatásának a kiküszöbölése megtörténik, rangsorképző mutatóként egy nettójelenérték-ráta adódik, mely tartalmilag a belsố kamatláb és a kalkulatív kamatláb különbsége. Ha a figyelembe vett kalkulatív kamatláb azonos, a nettójelenérték-ráta ugyanahhoz a rangsorhoz vezet, mint a belsô kamatláb (Illés, 2012a).

\section{Az aggregált tốkeigény fogalma, értelmezése}

A projekt aggregált tốkeigénye azt a tókemennyiséget jelenti, amely a projekt múködtetéséhez, annak teljes életideje alatt szükséges. Tipikus hozadéksorú beruházások esetén ezt alapvetôen három tényezố határozza meg: az induló tốke összege, a megtérülés időtartama (illetőleg az élettartam) és a megtérülés sebessége. Ez utóbbi kettó függ a figyelembe vett kalkulatív kamatláb nagyságától is.

A nagyobb aggregált tốkeigény fớbb megnyilvánulásai: nagyobb kezdôtóke, hosszabb megtérülési idő, lassúbb ütemú megtérülés, illetóleg ezek különbözó kombinációi. Egyirányú eltérések esetén egyértelmúvé tehetô, hogy melyik változatnak nagyobb az aggregált tốkeigénye. A valóságban azonban e három hatótényezô tetszóleges kombinációban, sốt egyidejúleg eltérô hatásirányokban jelentkezhet. Például az egyik változatnak nagyobb az induló tókeigénye, viszont rövidebb idő alatt, ámde lassúbb ütemben térül meg stb.

Az egyes projektek összesített tókeigényére vonatkozó információ szükségessége az irodalomban (ismereteim szerint) még utalás formájában sem merült fel. Következóleg a mutatószám meghatározására sem található szakirodalmi forrás.

Az aggregált tốkeigény meghatározásakor is az öszszefüggések idóben előrefelé haladó követése vezet egyértelmú eredményre. Ekkor a projekt élettartama során az egyes években lekötött tôkkeösszegekből lehet kiindulni. Ehhez körültekintés szükséges, ugyanis különböző évek tőkkelekötései általában nem összegezhetốk. A kamatos kamatszámítás szerinti megtérülési elvárás miatt egy egység tớkének a hároméves lekötése lényegesen nagyobb vállalati erôfeszítést jelent, mint három egység tốke egyéves lekötése.

Az aggregált tốkeigény számításakor az éveltérések összegzést zavaró hatásai oly módon küszöbölhetốk ki, hogy az egyes években lekötött tókeösszegek számszerúsítése a kamatos kamatszámítás szerinti jövedelmezőségi elvárással korrigált mutatószámokból kiindulva történik. Ekkor az éves hozadékoknak a nyereségkövetelménnyel csökkentett része vehető figyelembe tôkemegtérülésként. A meg nem térült tôke további nyereségigényt indukál, mely a következő évi hozadékokból térítendô meg stb.

Az ily módon számított éves tókelekötési tételek névértéken összegezhetốk. Az aggregált tớkeigény mértékegysége: egységnyi tóke egyéves lekötése. Az adott számítási mód eredményeképpen (és csak ebben az összefüggésben) egységnyi tókének a három évig tartó lekötése azonos három egység tókének az egyéves lekötésével. Mindkettô három egység aggregált tớkeigényt jelent. A számítás feltételezi, hogy az időben késóbb esedékes hozamok nagyobb bizonytalanságából fakadó nagyobb kockázat következményeit az évenkénti hozamok becslése során figyelembe vették.

Az összefüggések modellszerú levezetéséhez a kamatláb és a nyereségigény összefüggéséből célszerú kiindulni. 


\section{A kamatláb és a nyereségigény összefüggése}

A gazdaságossági szempontú nyereségigény kétféle módon függ a kalkulatív kamatlábtól. Egyrészt minél nagyobb a kalkulatív kamatláb, annál nagyobb nyereségigény keletkezik az adott tőkeösszegre vonatkoztatva. Másrészt minél nagyobb a kamatláb, annál nagyobb lesz az aggregált tókelekötés. Nagyobb kamatláb esetén ugyanis egy-egy adott évi hozadékból kisebb rész marad a befektetett tốke megtérítésére. Ezáltal idóben kitolódik, hosszabb ideig tart a tốkemegtérülés.

Az összefüggések részletesebb bemutatásához elsôként a nettójelenérték-görbét célszerú áttekinteni.

\section{A nettójelenérték-görbe}

A nettó jelenérték összege (egyébként változatlan feltételek mellett) a kalkulatív kamatláb függvényeként alakul. Ezt az összefüggést az irodalom a nettójelenértékgörbével jellemzi (1. ábra). A görbét a szerzők közismertnek tekintik, irodalmi hivatkozás nélkül szerepeltetik. Esetenként általános elvi összefüggésként szerepel (például Arnold - Hope, 1990), máskor példamegoldás eredményeként, illetôleg az összefüggés példán keresztuil történő bemutatásként ismertetik (például Brealy - Myers, 1988; Van Horne - Wachowicz, 2008).

A szakirodalomnak az 1-es ábrához füzött magyarázatai csupán a felszínt mutatják be. Eszerint minél nagyobb a kamatláb, annál kisebb nettó jelenérték adódik. A csökkenés folyamata elvezet a nulla nettó jelenértékig, majd a kamatláb további növelésének hatására egyre nagyobb negatív összegú nettó jelenérték keletkezik. A nulla a nettó jelenértéket eredményező kamatláb (mint közismert), maga a belsố kamatláb. Ennél a kamatlábnál metszi a görbe az $\mathrm{x}$ tengelyt. A modell feltételeinek és oksági hátterének szakirodalmi bemutatása nem ismeretes.

A legfóbb kérdés, hogy a modell érvényessége mennyiben tekinthetô általánosnak. Az 1. ábrán szereplô görbe ugyanis a reálisan szóba jöhetô projektek többségére igaz, de nem általános érvényú. A modell érvényességének a feltételei:

1. A projekt hozadéksora tipikus legyen. Ez a feltétel szükséges a nettójelenérték-görbe monoton csökkenő lefutásához. Ellenkezố esetben (nem tipikus hozadéksor esetén) több belsô kamatláb is létrejöhet, ami az ábra szempontjából azt jelenti, hogy a görbe több helyen metszheti az x tengelyt, vagyis hullámzóan alakulhat. (Közismert, hogy legfeljebb annyi belsố kamatláb jöhet létre, ahányszor az éves bevételek és kiadások különbségének idősora előjelet vált.)

2. A projekt számviteli megközelítésben legyen nyereséges. Ez a feltétel ahhoz szükséges, hogy a görbe a pozitív értéktartományból induljon. A tipikus hozadéksorú, ámde nem jövedelmezô, vagyis nyereséget nem eredményezô projekt nettó jelenértéke nem vehet fel pozitív értéket, a görbe lefutása nem indulhat a pozitív tartományból. Nulla névértékú nyereség esetén a görbe az origóból indulva halad lefelé. (Az összefüggés bizonyítására az alábbiakban kerül sor.)

Tipikus hozadéksorú és jövedelmező beruházások esetén az elhúzódó beruházásokra is megszerkeszthetố az ábra. Ekkor az üzemszerú múködés kezdetére számított kezdôtóke összege is függ a kalkulatív kamatlábtól, tehát nem fix tétel. Ez utóbbi összefüggés a modell általános alakját érdemben nem érinti, viszont valamelyest bonyolulttá teszi az összefüggések modellezését. A to-

1. ábra

A nettó jelenérték alakulása a számítás során alkalmazott kamatláb függvényében

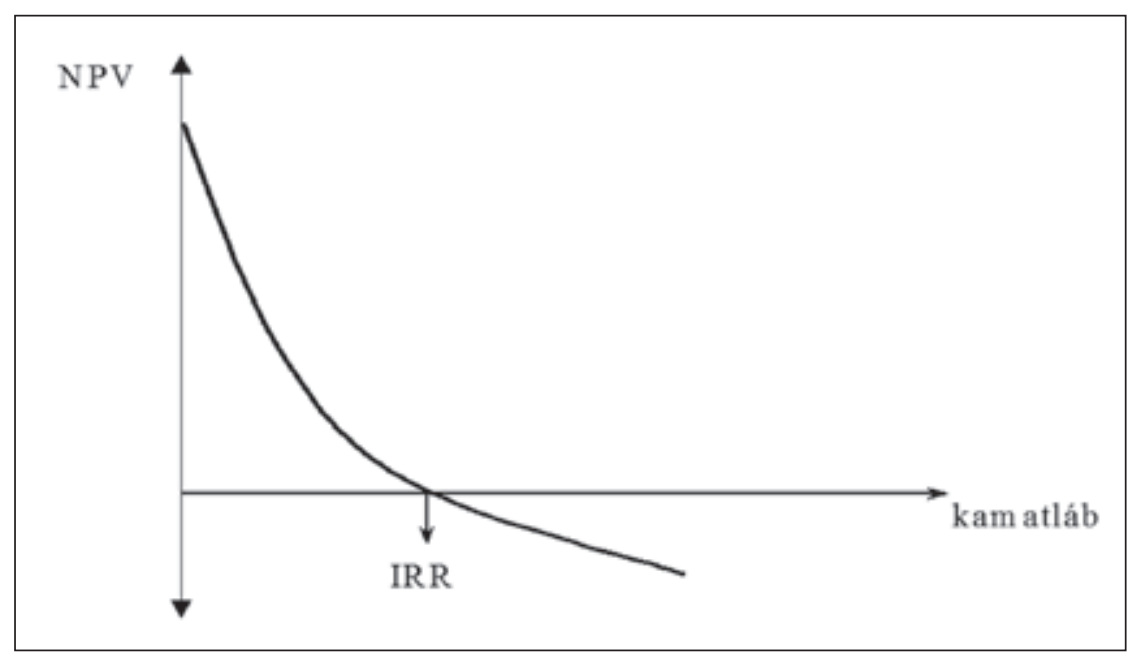

Forrás: az összefüggés közismertként használatos szakirodalmi ábrái

vábbiakban - egyszerúsítési célból - olyan modellek szerepelnek, ahol a kezdôtóke-szükséglet kifizetése egy időpontban merül fel. Ez nulladik időpontként szerepel, ettôl kezdve egy évvel késốbb jelentkezik az elsố hozadék. (A pontberuházás tehát nem modellfeltétel, csupán egy egyszerúsítési lépés. Az alapvető összefüggések feltárása után ez viszonylag egyszerúen feloldható.) 


\section{A kalkulatív kamatláb szerinti nyereségigény fedezeti forrása}

A nettójelenérték-számítás felszínen mutatkozó építkezési logikája nem követi a gazdálkodás idóbeli alakulásának a folyamatát. A vállalati stratégia kidolgozásakor, valamint a tervek összeállításakor - a tevékenységek egymásra épülési rendjének megfelelóen - a gyakorlati szakemberek elôrefelé gondolkoznak. Ehhez illeszkedik a jövedelmek keletkezésére és felhasználására vonatkozó gondolkodásmódjuk is. A megtérülési követelmények keletkezésének és teljesülésének időben előrehaladó vizsgálata szervesen illeszkedik a gazdasági szakemberek jövóépító gondolkozáshoz. Ez a vizsgálati mód összhangba hozható a nettójelenértékszámítással. Az idôszak végére kimutatható hozamtöbblet (hozamhiány) ugyanis egy egyszerú szorzással átszámítható nettó jelenértékre (Illés, 2012a).

Az alábbi (1) összefüggés a nettójelenérték-számítás tipikus hozadéksorú beruházásokra vonatkoztatott azon változatát mutatja, ahol az összes kezdőtőke-igény a nulladik idôpontban merül fel (pontberuházás).

$$
N P V=\sum_{t=1}^{n}\left(B_{f}-K_{t}\right) \frac{1}{(I+i)^{t}}-E_{o} \quad \mid B_{t}-K_{t}>0
$$

Jelölések:

$B_{t}=$ összes bevétel a t-edik évben,

$K_{t}=$ összes kiadás a t-edik évben,

$E_{0}=$ kezdôtóke,

$t=$ az évek sorszáma $(\mathrm{t}>0)$,

$n=$ a projekt élettartama,

$i=$ kalkulatív kamatláb (jövedelmezőségi elvárás).

A nettójelenérték-görbe a nullaszázalékos kamatlábtól indul. A nulla kalkulatív kamatláb behelyettesítésével a számítás statikus formulává alakul:

$$
N P V=\sum_{t=1}^{n} B_{t}-\sum_{t=1}^{n} K_{t}-E_{o}=M \quad \mid i=0
$$

$M=$ a teljes élettartam alatt keletkezô számviteli szemléletú nyereségösszeg (a teljes élettartam alatt keletkező összes bevétel és a kezdôtókével együtt számított összes kiadás névértékének a különbsége).

A (2) formula értelmében a nettó jelenérték nullaszázalékos kamatláb esetén egy számviteli szemléletú nyereségösszeg, mely a projekt teljes élettartamára vonatkozóan, névérték szerint összegzódött. A (2) formula azt is bizonyítja, hogy ha névértéken számítva nem keletkezik nyereség, a nettó jelenérték görbéjének lefutása nem indulhat a pozitív tartományból. (Ez egyben a közismert nettójelenérték-görbe 2. modellfeltételének szükségességét bizonyítja.) A teljes élettartamot átfogó, névérték szerinti számításban eltúnik az a különb- ség, hogy a számvitel nem a bevétel és a kiadás, hanem a bevétel és az összköltség éves különbségei szerint határozza meg a nyereséget.

A gazdálkodási folyamat szempontjából a nettójelenérték-számítás alapvetố tartalmi összefüggése: a kalkulatív kamatláb szerinti hozamelvárás fedezetéül a teljes élettartamot átfogó, névértéken számított nyereségösszeg szolgál. A módszer tartalmi mechanizmusa valójában ebbốl a névértéken számított nyereségöszszegból vonja le annak a nyereségkövetelménynek az összegét, amely a mindenkori tốkebefektetésre felszámítható. Az idôben elórefelé haladva az oksági öszszefüggések jól áttekinthetốk. Minden évben az addig még meg nem térült tóke összegére számítódik fel a kalkulatív kamatláb szerinti nyereségkövetelmény. (Az adott évi hozadékból nem fedezhetô nyereségkövetelmény a még meg nem térült tókéhez adódik.) Ha az összesített nyereségkövetelmény kisebb, mint a képzốdő nyereség névértékének az összege, akkor nyereségtöbblet keletkezik. Minél nagyobb kamatláb szerepel a számításban, annál kisebb lesz a nyereségösszeg névértékéból fennmaradó többlet, majd amikor ez már nem nyújt fedezetet az elvárásokra, hiány keletkezik. A nyereségtöbbleteknek (vagy hozamhiánynak) a nulladik idốpontra diszkontálása a nettó jelenértékhez vezet.

A nettó jelenérték számítási formulája a fenti tartalomtól eltérő felszínt mutat. Emiatt nem válik nyilvánvalóvá a legalapvetőbb összefüggés: a nyereségkövetelmény fedezeti forrása maga a nyereség.

\section{A nyereségkövetelmény megtérülésének folyamata}

Az adott évi bevétel és kiadás különbségeként értelmezett hozadék tartalmilag három összetevốból állhat:

- nyereségkövetelmény-megtérülési rész,

- tốkemegtérülési rész,

- többletnyereség.

Az egyes összetevő́k becslése során az adott évi hozadékból elsóként a nyereségkövetelményt kell teljesíteni. Ha a hozadék meghaladja az adott évi nyereségkövetelményt, a különbség tőkemegtérülésként értelmezhetô, és csökkenti a tốke további évekre vonatkozó névérték-megtérülési követelményét. Ha egy adott évi hozadék esetleg kisebb, mint az adott évre számított nyereségkövetelmény, akkor a különbség a még meg nem térült tốkeösszeghez adódik. A tôkemegtérülés üteme függ az induló tớke nagyságától, az éves hozadékok összegétól és a kalkulatív kamatlábtól.

Egy adott évi hozadékban többletnyereség csak a tốkealapú megtérülési követelmények, vagyis a tốke névértékének és a kalkulatív kamatláb szerinti hozamelvárásának teljesülését követôen keletkezhet. Miután megtérül az összes tőke és az összes hozamkövetel- 
mény, a hozadéktöbbletek tartalma többletnyereséggé válik. (Az 1. ábrán a tôkemegtérülés alakulása nem szerepel, csupán a számítás végeredménye, a keletkező hozamtöbbletek/hozamhiányok diszkontált összege.)

\section{A kalkulatív kamatláb szerinti nyereségigény számítása}

A fent kifejtettek értelmében a projekt múködésének egyes éveire névértéken számított nyereségigény az alábbiak szerint alakul (Illés, 2014):

Első évre:

$$
M_{s l}=E_{0} i
$$

Második évre: $\quad M_{s 2}=E_{1} i$; ahol $E_{1}=\left|H_{1}-E_{0} i-E_{0}\right|$

Harmadik évre: $M_{s 3}=E_{2} i$; ahol $E_{2}=\left|H_{2}-E_{1} i-E_{1}\right|$

Egy tetszóleges $t>1$ évre, ahol a megtérülési idő éveinek száma nem kisebb, mint a projekt élettartama:

$M_{s t}=E_{t-1} i ; \quad$ ahol $E_{t-1}=\left|H_{t-1}-E_{t-2} i-E_{t-2}\right| ; \quad \mid 1<\mathrm{t} \leq \mathrm{Z}$

$H_{t}=$ a $t$-edik évben a bevételek és a kiadások különbsége,

$E_{t}=$ a $t$-edik év végén még meg nem térült tôkeösszeg,

$M_{s t}=$ a t-edik évben keletkező, kalkulatív kamatláb szerinti nyereségszükséglet,

$\mathrm{z}=$ a dinamikus megtérülési idő éveinek száma.

Az 1-tól (z-1)-ig tartó években a hozadék két tartalmi összetevője: nyereségszükséglet és a tôkemegtérülési rész. Az összetevốk tartalmi különbözőségének láttatása céljából nem történt meg a matematikailag megoldható alábbi összevonás:

$$
H_{t-1}-E_{t-2} i-E_{t-2}=H_{t-1}-E_{t-2}(1+i)
$$

A projekt múködési ideje alatt felmerülő összes (számviteli szemléletû) nyereségigény:

$$
\begin{aligned}
& \sum_{t=l}^{n} M_{s t}=\sum_{t=1}^{n} E_{t-l} i \mid n \leq z ; \text { ahol } E_{t-l}=E_{0} t=1 ; \\
& \text { és } E_{t-1}=\left|H_{t-1}-E_{t-2} i-E_{t-2}\right| ; \mid t>1
\end{aligned}
$$

Ha a megtérülési idő nem rövidebb, mint az élettartam éveinek száma, akkor az összes névértéken számított nyereségtöbblet (vagy nyereséghiány) jelenértéke maga a nettó jelenérték:

$$
N P V=\left[M-\sum_{t=l}^{n} M_{s t}\right] \frac{1}{(1+i)^{n}} \quad \mid n \leq z
$$

Ha a megtérülési idő éveinek száma kisebb, mint a projekt élettartama (relatíve rövid a megtérülési idő), akkor vannak olyan évek, amikor tókealapú megtérülési követelmény már nincs, és így az adott évi hozadék teljes összege többletnyereségként szerepel. Ekkor a nettó jelenérték módszerével való összhang biztosítása érdekében az élettartam vége előtti években keletkező többletnyereségeket az élettartam végére fel kell kamatozni. Ez a kvázi kamat a diszkontálás során eltúnik.

A belsôkamatláb-keresés módszere a fentiekhez hasonló számítási mód szerint a tôkelekötést a teljes élettartamra értelmezi.

\section{Példa a kamatlábtól függố nyereségigény számítására}

A fentieket egy egyszerú példa szemlélteti. Az „A” projekt alapadatai: a nulladik időpontban felmerül 480 egység kiadás, majd ezt követően négy éven át minden évben 200 egység hozadék (bevétel-kiadás) keletkezik.

Az adatbázis szerint az ,A” projekt teljes élettartama alatt 320 egység névértékú nyereség keletkezik (800-480=320). Végsô soron a kamatláb függvényében ez a 320 egység oszlik meg nyereségelvárás szerinti megtérülésre és többletnyereségre, illetőleg a magasabb összegú nyereségelvárások esetén ehhez képest mutatkozik a nyereséghiány.

A vizsgálódás ötféle, tetszólegesen választott kamatláb szerint történik. A vonatkozó adatokat az 1 . táblázat foglalja össze. A részletező és magyarázó számítások a 2. táblázatban szerepelnek. Az összefüggések jobb átlátási lehetősége érdekében a számítások eredményei egész számokra kerekítve kerültek a táblázatokba.

1. táblázat

Az „A” projekt összesített nyereségigénye és ennek teljesülése a kalkulatív kamatláb függvényében

\begin{tabular}{|l|c|c|c|c|c|}
\hline \multicolumn{9}{|c|}{ Mértékegység: egység } \\
\hline Kamatláb & $0 \%$ & $8 \%$ & $20 \%$ & $24 \%$ & $30 \%$ \\
\hline A teljes nyereségigény-névérték összege & 0 & 72 & 241 & 320 & 453 \\
\hline Hozamtöbblet/hozamhiány a 4. év végére számítva & 320 & $248^{*}$ & 79 & 0 & -133 \\
\hline NPV (a 4. év végére számított többlet/hiány jelenértéke) & 320 & 182 & 38 & 0 & -47 \\
\hline
\end{tabular}

*Az összeg négy egység technikai hozamtöbbletet tartalmaz. Részletezése a 2. táblázat szerint. 
Az 1. táblázatban is látható, minél nagyobb a nyereségelvárás, annál kisebb a többletnyereség. A nyereségelvárások összegei és a többletnyereségek névérték szerinti összegei mindegyik változat esetében kiadják a 320 egységet. (Hozamhiány esetén az évenkénti nyereségelvárások összegének és a hozamhiányok összegének a különbsége vezet el a 320 egység nyereséghez.) A 24 százalék egyben a belső kamatláb is. Itt értelemszerúen nincs se hozamtöbblet, se hozamhiány. b) Az időszak végére számított hozamtöbblet diszkontált összege: $\quad 248 \times 0,73503=182$

Mint a 2. táblázatban látható, a nyereségelvárások éves összegei a még meg nem térült tôkeösszeg és a kalkulatív kamatláb szorzataként alakulnak. Az évenként keletkező 200 egység hozam egyrészt fedezetet nyújt az adott évi nyereségkövetelményre, majd a fennmaradó rész csökkenti a még meg nem

2. táblázat

A számítás bemutatása 8, 20, 24 és 30 százalékos

kalkulatív kamatláb esetére

\begin{tabular}{|c|c|c|c|c|}
\hline \multirow{2}{*}{$\begin{array}{l}\% / \\
\text { évek }\end{array}$} & \multirow{2}{*}{$\begin{array}{l}\text { Megtérülésre váró tóke- } \\
\text { összeg az adott év elején/ } \\
\text { előzó évi többletnyereség }\end{array}$} & \multicolumn{2}{|c|}{$\begin{array}{c}\text { Az adott évi } 200 \text { egység hozadék megtérülési } \\
\text { struktúrája }\end{array}$} & \multirow{2}{*}{$\begin{array}{l}\text { Év végén a projektben maradó, meg- } \\
\text { térülésre váró tókeösszeg (-), illetôleg } \\
\text { a keletkezố többletnyereség (+) }\end{array}$} \\
\hline & & Nyereségelvárás & Tókemegtérülés & \\
\hline \multicolumn{5}{|c|}{$8 \%$} \\
\hline 1. & 480 & 38 & 162 & $-480+162=-318$ \\
\hline 2. & 318 & 26 & 174 & $-318+174=-144$ \\
\hline 3. & 144 & 12 & 188 & $-144+188=+44$ \\
\hline 4. & Többletnyereség: 44 & \multicolumn{2}{|c|}{ Többletnyereség: $200+4^{*}$} & $+44+204=+248$ \\
\hline \multicolumn{5}{|c|}{$20 \%$} \\
\hline 1. & 480 & 96 & 104 & $-480+104=-376$ \\
\hline 2. & 376 & 75 & 125 & $-376+125=-251$ \\
\hline 3. & 251 & 50 & 150 & $-251+150=-101$ \\
\hline 4. & 101 & 20 & 180 & $-101+180=+79$ \\
\hline \multicolumn{5}{|c|}{$24 \%$} \\
\hline 1. & 480 & 116 & 84 & $-480+84=-396$ \\
\hline 2. & 396 & 95 & 105 & $-396+105=-291$ \\
\hline 3. & 291 & 70 & 130 & $-291+130=-161$ \\
\hline 4. & 161 & 39 & 161 & $-161+161=0$ \\
\hline \multicolumn{5}{|c|}{$30 \%$} \\
\hline 1. & 480 & 144 & 56 & $-480+56=-424$ \\
\hline 2. & 424 & 127 & 73 & $-424+73=-351$ \\
\hline 3. & 351 & 105 & 95 & $-351+95=-256$ \\
\hline 4. & 256 & 77 & 123 & $-256+123=-133$ \\
\hline
\end{tabular}

" A számítás összhangjának biztosítása érdekében az idôszak vége előtt keletkező többletnyereségeket az idôszak végére fel kell kamatozni $(44 \times 0,08=4)$. Ez csupán egy technikai múvelet, és csak azokat a változatokat érinti, ahol a megtérülési idó éveinek száma kevesebb, mint a projekt élettartama. Az időszak végére számított többletnyereség nulladik időpontra történő diszkontálása során az így felszámított kamat eltûnik. (A valóságban a megtérülési követelményeket teljesítő hozadékokhoz hasonlóan a 3. év végén a 44 egység többletnyereség is kilép a projektből, számára is megfelelően jövedelmező befektetési lehetőséget kell keresni. A 4. év végén keletkező 200 egység hozadéknak a projektból való kilépése természetes, hiszen ekkor a projekt élettartama véget ér.)

A nettó jelenérték ellenőrzó számítása 8 százalékos kalkulatív kamatláb esetén:

a) A kezdőtóke összegének és a hozadékok diszkontált összegének a különbsége:

$$
-480+\frac{200}{0,30192}=-480+662=182
$$

térült tôkeösszeget mindaddig, amíg az összes tôke meg nem térül. A megtérülés évében a nyereségelvárás és a tôkemegtérülés feletti rész többletnyereség. Az ezt követô években keletkezô hozadékok már a teljes összegükre vonatkozóan többletnyereséget jelentenek.

\section{VEZETÉSTUDOMÁNY}




\section{Az aggregált tốkeigény becslése}

\section{A becslés folyamatmodellje}

Az egyes években lekötött tôke idôsora a (3), (4), (5), (6) szerinti összefüggésekbe beépítetten szerepel. Ezek szerint a projekt múködésének egyes éveire vonatkozóan a még meg nem térült tốkeösszeg meghatározásának folyamata (Illés, 2014):

A múködés elsố évében a kezdőtóke teljes értékben le van kötve a projektben:

$E_{0}$

A második év során a lekötött tớke annyival kisebb, mint amekkora tôkerész megtérült az elsố évi múködés eredményeként:

$$
E_{l}=\left|H_{1}-E_{0} i-E_{0}\right|
$$

A harmadik év során a második évi múködés során keletkezố tốkemegtérüléssel csökken a lekötött tốke összege:

$$
E_{2}=\mid H_{2}-E_{1} i-E_{1}
$$

Egy adott év során mindig az előző év végén meglévố tôkeösszeg szerepel tốkelekötésként. (Az elsố év tốkelekötése a nulladik idôpontban megvalósult befekte-

$$
E_{A}=\sum_{t=1}^{n} E_{t-l}
$$

\section{Az aggregált tókeigény számításának példaszerú} bemutatása

A fentiekben szereplő „A” projekt nyereségigényének számításai során (a modellszerú levezetésekkel egyezően) kellett határozni az egyes években lekötött tốkeösszeget is. Így a 2. táblázatban összefoglalt számítási anyagok tartalmazzák az egyes évek tókelekötési összegeit is. Az „A” projekt aggregált tókeigényének számszerúsítéséhez ezeket kell összegezni.

Az összegzett adatok a 3. táblázatban szerepelnek. A számok tükrében is látható, hogy az egyes évek tốkelekötési összegei (egyébként változatlan feltételek mellett) a figyelembe vett kamatláb függvényeként alakulnak. Minél nagyobb a nyereségelvárás, annál kisebb rész marad tốkemegtérítésre. A lassúbb megtérülésból következően egyre nagyobb lesz ugyanannak a projektnek az aggregált tókeigénye. (A figyelembe vett széles kamatsáv szemléltetési célokat szolgál.)

$\mathrm{Az}$ „A” projekt belsô kamatlába, vagyis valódi tôkejövedelmezốsége 24 százalék. Az aggregált tốkeigény

3. táblázat

\begin{tabular}{|c|c|c|c|c|c|}
\hline \multirow[t]{2}{*}{ Évek } & \multicolumn{5}{|c|}{ A projekt tőkeigénye a kamatláb függvényében } \\
\hline & $\mathbf{0 \%}$ & $8 \%$ & $20 \%$ & $24 \%$ & $30 \%$ \\
\hline 1. & 480 & 480 & 480 & 480 & 480 \\
\hline 2. & 280 & 318 & 376 & 396 & 424 \\
\hline 3. & 80 & 144 & 251 & 291 & 351 \\
\hline 4. & - & - & 101 & 161 & 256 \\
\hline Aggregált tőkeigény & 840 & 942 & 1208 & 1328 & $\begin{array}{c}1511 \\
\text { (Nem térül meg) }\end{array}$ \\
\hline
\end{tabular}

Az ,A” projekt aggregált tốkeigényének számítása különbözó kalkulatív kamatlábak mellett

tetési összeg, a második év során az első év végén még meg nem térült tókeösszeg szerepel tókeállományként stb.) A $t$-edik év során a tókelekötés összege $\mathrm{E}_{\mathrm{t}-1}$. Az első évben a projekt kezdőtókéje szerepel tôkelekötésként $\left(\mathrm{E}_{0}\right)$, ez az alapadatok között szerepel. A második évtől kezdve a megtérülési idő végéig minden évre vonatkozóan ( az $1<t \leq z$ évekre) külön számítást igényel a tókelekötés meghatározása:

$$
E_{t-1}=\left|H_{t-1}-E_{t-2} i-E_{t-2}\right| ; \quad \mid 1<t \leq z
$$

Az össztôkeszükséglet meghatározásához az egyes években megtérülésre váró tốkeösszegek sorának öszszegzése vezet el az aggregált tôkeigényhez. Ennek értelmében az aggregált tôkeigény $\left(E_{A}\right)$ a következóképpen számítható: ismeretében a projekt gazdasági értéke: 1328 egység tốke egyéves lekötése 24 százalékos nyereséghozamot eredményez. És valóban: $328 \times 0,24=319$ egység, ami (a kerekítési hibáktól eltekintve) megegyezik a projektnek az eredeti adatok szerint számított 320 egység névértékû nyereségével.

\section{Az aggregált tốkeigény szemléletformáló erejének bemutatása példán keresztül}

Az aggregált tôkeigény ismeretének jelentőségét az alábbiakban egy olyan speciális példa szemlélteti, ahol két projektváltozatra vonatkozóan a rangsorolásra javasolt nettójelenérték-alapú mutatók mind azonosak, azonban a két projekt gazdasági értéke mégis jelentősen különbözik. Az alapadatokat a 4. táblázat tartalmazza. 
Két projektváltozat bevételi és kiadási sorai*

\begin{tabular}{|l|c|c|c|c|c|c|}
\hline \multirow{2}{*}{ Időpont } & \multicolumn{3}{|c|}{,B” projektváltozat } & \multicolumn{3}{c|}{,C” projektváltozat } \\
\cline { 2 - 7 } & Kiadás & Bevétel & Hozadék & Kiadás & Bevétel & Hozadék \\
\hline 0. & 350 & 0 & -350 & 350 & 0 & -350 \\
\hline 1. & 512 & 517 & 5 & 496 & 896 & 400 \\
\hline 2. & 653 & 658 & 5 & 701 & 706 & 5 \\
\hline 3. & 312 & 812 & 500 & 828,488 & 833 & 4,512 \\
\hline
\end{tabular}

*Az összegek dimenziója: egység

Nyereségösszegek:

- „B” projekt nyereségének névértéke $510-350=$ 160 egység,

- „C” projekt nyereségének névértéke 409,512 $350=59,5$ egység.

\section{Projektértékelés nettójelenérték-preferencia mellett}

A nettójelenérték-preferencia projektértékelére ajánlott mutatószámainak alakulása 12 százalékos kalkulatív kamatláb mellett:

a) a nettó jelenérték mindkét esetben: 14,3 egység,

b) a beruházás egységére jutó nettó jelenérték mindkét esetben: 14,3/350 = 0,041 egység,

c) a jövedelmezôségi index mindkét esetben: $364,3 / 350=1,041$

d) a nettó jelenérték éves gazdasági átlaga mindkét esetben: $0,41635 \times 14,3=5,95$ egység.

Mint látható, a nettójelenérték-preferencia bármely irányzata szerinti rangsorképzés egyenértékủnek mutatatja a két projektet, holott messze nem egyenértékúek. Egyrészt eltérô a két projekt aggregált tő́keigénye, másrészt eltérôek a belsô kamatlábak. A nettójelenértékpreferencia szempontjából az aggregált tốkeigény eltérése tekinthetó érdemleges projektinformációnak.

A 12 százalékos kalkulatív kamatláb mellett adódó aggregált tókeigények:

- „B” projekt aggregált tókeigénye 1165 egység,

- „C” projekt aggregált tőkeigénye 350 egység.

Az aggregált tốkeigény eltérése az adott esetben kizárólag a megtérülési sebesség különbözőségéből következik. A „C” projekt 350 egység beruházási összegét már az első év végén meghaladja a 400 egység hozadék. Ez a 400 egység kilép a projektből, más területen lehet hasznosítani, újra befektetni. Az ezt követő két évben mindössze 4,5-5 egység bevételi többlet (hozadék) keletkezik annak ellenére, hogy a tevékenység árbevétele csupán mintegy 10-15 százalékkal csökken. Ezzel szemben a „B” projektváltozatnál az első két év hozadé- kai csak 5-5 egységgel járulnak hozzá a tóke és a nyereségelvárás megtérüléséhez. 500 egység, vagyis a pozitív összegú hozadék 98 százaléka a harmadik év végén keletkezik, ami azt jelzi, hogy érdemi újrabefektetési lehetőségre ekkor nyílik lehetôség. A lassúbb megtérülés miatt a „B” projekt összesített tókeigénye mintegy háromszorosan meghaladja a „C" projektét.

Ha a nettó jelenérték maximálása volna a cél, akkor egyrészt „C” projekt a „B”-hez viszonyítottan egyharmadnyi össztőkeigénnyel teljesíthetné a 14,3 egység nettó jelenértéket, másrészt a fennmaradó össztókerészt további nettó jelenértékek fialtatására lehetne fordítani. Az adott mutatószámok mellett ennek a belátása az aggregált tốkeigény ismerete nélkül kissé nehézkes volna. (Az más kérdés, hogy a nettó jelenérték és az ajánlott származtatott mutatói alapján történő projektértékelés nem illeszkedik a hosszú távú profitmaximálás koncepciójához. Részletezés: Illés, 2012a.)

\section{Projektértékelés belsókamatláb-preferencia mellett}

Tekintettel a két projektváltozat hozadéksorának tipikus voltára, a belső kamatláb a projektekbe befektetett tốke jövedelmezôségét számszerúsíti. Emellett a gazdasági értékeléshez nagyban hozzájárulhat az aggregált tókeigény ismerete.

- „B” projekt belső kamatlába 13,5 százalék, aggregált tốkeigénye 1182 egység. Ez a gazdasági érték szempontjából azt jelenti, hogy 1182 egység tóke egyéves lekötés mellett hoz 13,5 százalék nyereséget. Számítása: $1182 \times 0,135$ $=159,6$. Valóban azt jelenti, mivel az aggregált tốkeigény és a tényleges jövedelmezôségi ráta szorzata - a kerekítési hibáktól eltekintve - megegyezik az eredeti adatokból számított 160 egység névértékú nyereséggel.

- „C” projekt belsố kamatlába 16,5 százalék, aggregált tókeigénye 362 egység. A gazdasági érték: 362 egység tóke egyéves lekötés mellett 16,5 százalékos nyereségráta mellett múködik. Számítása: $36 \times 20,165=59,7$ egység. 
Az aggregált tôkeigény és a jövedelmezôségi ráta szorzata - a kerekítési hibáktól eltekintve itt is megegyezik az eredeti adatokból számított 59,5 egység névértékú nyereséggel.

(Ennél a számításnál az egyes projektek aggregált tőkeigénye eltér attól, ami a 12 százalékos kalkulatív kamatláb mellett adódott. A nem túlzottan jelentős eltérést a számítás során figyelembe vett kamatlábak különbözôsége okozza.)

Összességében a „C” projekt a „,B”-hez képest határozottan alacsonyabb aggregált tôkeösszegre jelez három százalékponttal magasabb tôkejövedelmezôségi lehetőséget. A két változat közötti jó választás érdekében azt célszerú vizsgálni, hogy milyen jövedelmezôségi esélyekkel lehet „C” hozadékkülönbségeit újra befektetni (a másik projekt élettartamának a végéig), majd ezt egybe kell vetni az újrabefektetés kritikus jövedelmezóségi rátájával (mely ahhoz szükséges, hogy a „C” projekt valamely más projektkombinációval az időszak végére legalább akkora tôkejövedelmezőséget érjen el, mint a „B” projekt).

Adott esetben a hozadékkülönbözetek újrabefektetésének kritikus jövedelmezôségi rátája $\left(\mathrm{r}_{\mathrm{k}}\right)$ :

$$
\begin{aligned}
& 395\left(1+r_{k}\right)^{2}=495,488 ;\left(1+r_{k}\right)^{2}=1,2544 ; \\
& 1+r_{k}=1,12, \text { azaz } 12 \%
\end{aligned}
$$

Az újrabefektetés kritikus jövedelmezőségi rátája 12 százalék. Ennek ismeretében azt kell vizsgálat tárgyává tenni, hogy a hozadékkülönbözetekre vonatkozóan adódik-e lehetôség a 12 százalékot bármilyen kis mértékben is meghaladó jövedelmezôségú újrabefektetésre. Amennyiben ez a lehetőség eléggé nagy biztonsággal feltételezhető, akkor a „C” változatot célszerú választani. Ha nem látszik lehetôség a hozadékkülönbözeteknek legalább 12 százalékos jövedelmezôségú befektetésére, akkor a „B” változat a kedvezóbb.

\section{Összegzés}

A beruházásgazdaságossági számítások standard módszerei a felszínen globálisan egységesnek látszanak, azonban az eltérô diszciplináris háttér miatt igen komoly elvi-módszertani eltéréseket tartalmaznak. Közös jellemzőjük, hogy nem veszik figyelembe (és nem is vizsgálják) a projektek összesített tôkeigényét. Az irodalomban a projektek aggregált tốkeigénye még fogalmi szinten sem szerepel.

Jelen tanulmány a vállalati gazdaságtan felfogása, szemléletmódja és feltételrendszere alapján határozza meg a beruházási projektek összesített tókeigényének fogalmát, vizsgálja annak becslési lehetőségét, és dolgozza ki a becslés módszerét. Az egyértelmúség érdekében meghatározza a közismert nettójelenérték-görbe modelljének a feltételrendszerét. A nulla kamatláb mellett számított nettó jelenérték összege rámutat, hogy a nyereségkövetelmény megtérülésének tartalmi forrása a projekt teljes életideje alatt keletkezô, névértéken számított nyereségösszeg. A megtérülés folyamatának idốben előrefelé haladó nyomon követése megismerhetővé teszi a belső tartalmi összefüggéseket.

Az aggregált tốkeigény becslésének kiinduló öszszefüggése, hogy a projekt múködésének egyes éveiben keletkező hozadékokból a nyereségkövetelmény levonása után fennmaradó rész fordítódik a tôke névértékének a megtérülésére. A meg nem térült tôkerész továbbra is a projektben marad, az aggregált tôkeigény részét képezve. Az adott számítási mód következménye a különböző évek tôkelekötéseinek összegezhetősége, továbbá, hogy az aggregált tôkeigény függ a figyelembe vett kamatláb nagyságától is.

Az aggregált tốkeigény a projekt életidejének egyes éveiben lekötött tôkék összegzése révén határozható meg. Mértékegysége az egységnyi tóke egyéves lekötése. A mutatószám egyformán három egység tôkének minősíti a három egység tôke egyéves lekötését, és az egységnyi tôke hároméves lekötését. Az aggregált tókeigény és a belsó kamatláb szorzata a projekt által eredményezett nyereség névértékével azonos.

Az aggregált tókeigény ismeretének a szemléletformáló ereje is igen jelentős. A tanulmány bemutat egy példát, melyben a vizsgált két projektnek azonos az induló tókebefektetése, azonos az élettartama, továbbá azonos a nettójelenérték-dominancia mellett összehasonlításra javasolt mind a négy mutatószáma. A két projekt gazdasági szempontból mégsem tekinthetô egyenértékúnek. Az aggregált tôkeigény mutatószámában ugyanis több mint háromszoros eltérés van, és a projektek valódi tôkejövedelmezősége is jelentős eltérést mutat.

A vállalat elvileg akkor éri el a legnagyobb növekedési lehetőséget, ha mindenkor a (projektkockázattal előzetesen kezelt) legnagyobb belsố kamatláb szerinti projekteket, illetôleg projektkombinációkat valósítja meg. (Részletesebben: Illés, 2012a.)

\section{Felhasznált irodalom}

Albrecht, W.S. - Stice, J.D. - Stice, E.K. - Swain, M.R. (2007): Accounting: Concepts and Applications. Andover: Cengage Learning Thomson South-Western Arnold, J. - Hope, T. (1990): Accounting for Management Decisions. London: Prentice Hall International (UK) Ltd. 
Baker, H.K. - Powell, G. (2009): Understanding Financial Management: A Practical Guide. Chichester: John Wiley \& Sons

Bierman, H. - Smidt, S (1986): Financial Management for Decision Making. New York: Macmillan

Brealey, R.A. - Myers, S.C. (1988): Principles of Corporate Finance. New York: McGraw-Hill Publishing Company

Brigham, E.F. - Ehrhardt, M.C. (2008): Financial Management: Theory \& Practice. Mason, Oh: Thomson South-Western

Böhm-Bawerk, E.V. (1889): Positive Theorie des Kapitales. Jena: Fisher

Böhm-Bawerk, E.V. (1891): The Positive Theory of Capital. London; New York: MacMillan and Co.

Crundwell, F.K. (2008): Finance for Engineers. Evaluation and Funding of Capital Projects. London: SpringerVerlag London Limited

Damodaran, A. (2010): Applied Corporate Finance. Hoboken: John Wiley \& Sons Inc.

Firer, C. - Gilbert, E. (2004): Investment Basics XLVIII. Common challenges in capital budgeting; Investment Analysts Journal, No. 59: p. 41-45.

Fisher, I. (1930): The Theory of Interest. New York: Macmillan

Illés M. (1990): A gazdaságossági és jövedelmezôségi számítások alapjai. Budapest: Szakszervezetek Gazdaság- és Társadalomkutató Intézete

Illés, M. (2007): Scientific Problems of Modern Approach of Net Present Value. Club of Economics in Miskolc, TMP, Nr. 1: p. 29-35.

Illés M. (2012a): A nettó jelenérték gazdasági tartalma és rangsorképzésre való alkalmassága. Vezetéstudomány, Különszám: 13-23. o.

Illés, M. (2012b): Links Between Net Present Value and Shareholder Value form a Business Economics Perspective. Club of Economics in Miskolc. TMP, Vol. 8, Nr. 2: p. 31-36.
Illés, M. (2014): Fisher's Rate and Aggregate Capital Needs in Investment Decisions. Club of Economics in Miskolc, TMP, Nr. 1,: p. 21-32.

Keane, S.M. (1975): Investment selection criteria: an examination of the theory of the internal rate of return and of the investment discount rate under conditions of uncertainty. $\mathrm{PhD}$ thesis. Glasgow: University of Glasgow

Keynes, J.M. (1936): The General Theory of Employment, Interest and Money. New York: Macmillan

Khan, M.Y. - Jain, P.K. (2008): Financial Management. New Delhi: Tata McGraw-Hill

Kinney, M. - Raiborn, C. (2011): Cost Accounting: Foundations and Evolutions. Mason, Oh: South-Western Cengage Learning

Laux, J. (2011): Topics in Finance Part VI - Capital Budgeting; American Journal of Business Education Volume 4, Number 7: p. 29-38.

Szúcsné Markovics K. (2012): A beruházásgazdaságossági számítások gyakorlatban alkalmazott módszerei. Vezetéstudomány, Különszám: p. 97-106.

Van Horne, J.C. - Wachowicz, J.M. jr. (2008): Fundamentals of Financial Management. Harlow: Pearson Education Limited

Volkman, D.A. (1997): A consistent yield-based capital budgeting method. Journal of Financial and Strategic Decisions, Volume 10, Number 3: p. 75-88.

Watson, D. - Head, A. (2009): Corporate Finance: Principles and Practice. Harlow: Pearson Education Limited

Woods, J.C. - Randall, M.R. (1989): The Net Present Value of Future Investment Opportunities: Its Impact on Shareholder Wealth and Implications for Capital Budgeting Theory. Financial Management, Vol. 18, No. 2: p. 85-92. 